\title{
Groundwater Hydrochemical Zoning in Inland Plains and its Genetic Mechanisms
}

\author{
Liting Xing ${ }^{1,2}$, Linxian Huang ${ }^{1,2, *}$, Xinyu Hou ${ }^{1}$, Lizhi Yang ${ }^{3}$, Guangyao Chi ${ }^{1}$, Junxiang Xu ${ }^{4}$ \\ and Henghua $\mathrm{Zhu}^{3}$ \\ 1 College of Hydraulic and Environmental Engineering, University of Jinan, Jinan 250022, China; \\ stu_xinglt@ujn.edu.cn (L.X.); hxy1434672208@outlook.com (X.H.); \\ shandongchiguangyao@hotmail.com (G.C.) \\ 2 Engineering Technology Institute for Groundwater Numerical Simulation and Contamination Control, \\ Jinan 250022, China \\ 3 Shandong Insititute of Geological Survey, Jinan 250014, China; ylz200456@163.com (L.Y.); \\ hhzhu2008@sina.com (H.Z.) \\ 4 Shandong Provincial Bureal of Geology and Mineral Resources, Jinan 250013, China; xjx3462@sina.com \\ * Correspondence: stu_huanglx@ujn.edu.cn; Tel.: +86-183-9688-9589
}

Received: 3 May 2018; Accepted: 6 June 2018; Published: 8 June 2018

\begin{abstract}
Pore water in inland plain areas, generally having poor water quality, contain complex hydrochemical properties. In order to examine groundwater chemical composition formation characteristics, groundwater in the Jiyang area of Lubei Plain was studied using stratified monitoring of drilling, analysis of water level and water quality, isotope analysis, ion ratio coefficient and isothermal adsorption experiments, hydrochemical characteristics, and analysis of variations in different shallow depths. Results show that: (1) Numerous hydrochemistry types are present in the diving. Along with the direction of groundwater flow, total dissolved solids (TDS) of diving in the study area generally increases and the hydrochemical type changes from the $\mathrm{HCO}_{3}$ type to the $\mathrm{HCO}_{3} \cdot \mathrm{SO}_{4}$ type, $\mathrm{Cl} \cdot \mathrm{HCO}_{3}$ type and the $\mathrm{Cl} \cdot \mathrm{SO}_{4}$ type. (2) Shallow brackish water and freshwater in the horizontal direction are alternately distributed, and shallow brackish water is distributed in the area between old channels, showing sporadic spots or bands, whose hydrochemistry type is predominantly $\mathrm{Cl} \cdot \mathrm{SO}_{4}-\mathrm{Na} \cdot \mathrm{Mg} \cdot \mathrm{Ca}$. (3) Affected by the sedimentary environment, hydrodynamic conditions and other factors; diving, middle brackish water and deep freshwater are vertically deposited in the study area. The dynamics of middle brackish water quality are stable due to the sedimentary environment and clay deposits. The hydrochemistry types of middle brackish water are mainly $\mathrm{Cl} \cdot \mathrm{SO}_{4}-\mathrm{Mg} \cdot \mathrm{Na}$ and $\mathrm{SO}_{4} \cdot \mathrm{Cl}-\mathrm{Na} \cdot \mathrm{Mg}$, while the deep confined water is dominated by $\mathrm{HCO}_{3}$. (4) The optimal adsorption isotherms of $\mathrm{Na}^{+}, \mathrm{Ca}^{2+}$ and $\mathrm{Mg}^{2+}$ in groundwater from clay, with a thickness raging from 6-112 m, conformed to the Henry equation and the Langmuir equation. The retardation of $\mathrm{Na}^{+}, \mathrm{Ca}^{2+}$ and $\mathrm{Mg}^{2+}$ in groundwater differed with differing depths of the clay deposit. The trend of change in retardation strength correlates strongly with the TDS of groundwater. Groundwater in the inland plain area is affected by complicated hydrogeochemical processes; in addition, leaching, cation exchange, evaporative concentration and clay retardation have an important influence on the horizontal and vertical zonation of groundwater chemical components.
\end{abstract}

Keywords: inland saltwater; retardation; horizontal zonation; vertical zonation; hydrogeochemistry

\section{Introduction}

The chemical composition of groundwater, especially brackish water in inland plains, is controlled by numerous factors such as meteoric, climatic, hydrological, geological background, hydrodynamic 
conditions and the hydrochemical field. The genetic type and evolution of groundwater are extremely complicated. Quaternary sediments in North China have been subjected to multiple transgressions and salinization effects, and they are widely distributed in shallow freshwater, mid-deep saline water and deep freshwater. The shallow pore water in the western part of North China is mainly affected by the salinization of the continent [1,2]. The relative lack of freshwater resources, insufficient utilization of inland saltwater bodies, and the deep over-exploitation of freshwater have resulted in land subsidence [3,4]. Since inland saltwater has been regarded as an unconventional and inferior water source, the current understanding of the alternating role of fresh and brackish water in inland plains is not well developed. Study on the characteristics, chemical composition and the causes of inland groundwater, which not only has important academic significance, but also important practical value of developing and utilizing groundwater resources rationally $[5,6]$.

The chemical composition of groundwater is the product of the long-term interaction between groundwater and the surrounding environment $[7,8]$. During the evolution of a groundwater system, different hydrogeochemical processes result in groundwater having different chemical compositions [9], manifested as certain hydrochemical zonality [10,11], which is widely used in groundwater hydrochemistry and its genetic mechanisms [12,13]. In order to compare the formation processes of groundwater's chemical composition, the Piper trilinear nomograph, the Shukalev classification and kurllov's formula have been traditionally used [14,15]. Currently, statistical analysis, isotope analysis and ion proportion coefficient analysis are often used to characterize the variability in chemical compositions of groundwater $[16,17]$. For example, monitoring the variation of isotopic composition can distinguish their different origins $[18,19]$. The ion ratio coefficient can be used to analyze the hydrogeochemical effects experienced by groundwater [20,21], and to invert the formation of groundwater hydrochemistry [22,23].

Previous studies have shown that water-rock interaction, water evaporation, solute dissolution, evaporation concentration and mixing action have important effects on the chemical type of groundwater [24,25]. The aquifer medium can, to a certain extent, block the migration of ion components in groundwater, thus affecting the chemical composition [26,27]. The strength of the retardation is not only related to the nature of the media $[28,29]$, but also to the properties of the components in the aqueous solutions [30,31]. The aquifer media can also adsorb groundwater contaminants [32,33], indicating that adsorption is one of the factors that affects its retarding properties $[34,35]$. However, studies on the retardation of the aquifer have predominantly focused on blocking pollutants in groundwater [36,37]. The media is less concerned by studies on conventional ion retardation in groundwater. Clay retardation can also be considered as an important hydrogeochemical process in groundwater systems. It is important to carry out relevant research for the rational development and application of groundwater [38].

Groundwater in inland plain areas mainly occur in newly accumulated loose sediments. The aquifer medium is mainly composed of clay and powdery sticky sand containing thin silt sand. The clay aquitard is an important part of the inland plains groundwater system $[39,40]$, and it cannot ignore that clay retarding action has a significant impact on the evolution of hydrochemical composition [41]. Thus, taking the Jiyang area of Lubei Plain as a case, the zonal characteristics and genetic mechanisms of groundwater hydrochemical composition in an inland plain area are investigated using core drilling, long-term monitoring of the groundwater dynamics, stratified sampling, and routine groundwater ion tests. Ion ratio coefficient and isotope analysis are also used to provide a scientific basis for the evolution of brackish water. 


\section{Research Area Overview}

The research area was located in Jiyang County and parts of Shanghe County, Linyi County, Qihe County (Figure 1). The study area, being hot and rainy in the summer and cold and dry in the winter, is characterized by a warm, temperate, humid continental monsoon climate. Affected by frequent diversions of the Yellow River, paleoclimate and other factors, this area has a complex sedimentary environment and contains alluvial and lacustrine [7]. Groundwater depth less than $500 \mathrm{~m}$ can be divided into three aquifer types. From top to bottom they are: (i) Shallow diving type (up to a depth of $40 \mathrm{~m}$ ), having a silt and fine silt lithology; (ii) middle confined water type (60-200 m), having a sand, medium sand and fine sand lithology, shallow diving type and middle confined water type, separated by clay and silty clay aquitard; and (iii) deep confined water (roof depth of 200-300 m and a floor depth of 450-500 m), having a lithology comprising a predominantly silty clay, clay and a thin layer of fine sand (Figure 2).

The source of diving recharge in the study area is mainly atmospheric precipitation and surface water. The terrain in the study area descends from the southwest to the northeast, having a slope of 1/7000-1/8000 (Figure 1). Ground elevation is between 18-20 m. Because of the slow movement of groundwater and the small gradient, evaporation becomes the main means of discharge route [6]. The middle confined water and deep confined water were formed during the ancient geological period, and their recharge time and supply path were longer. The water quality of the middle confined water is poor, and the exploitation and utilization are less; the deep confined water is mainly excreted manually, and may be supplied by diving and over-flow of middle confined water.

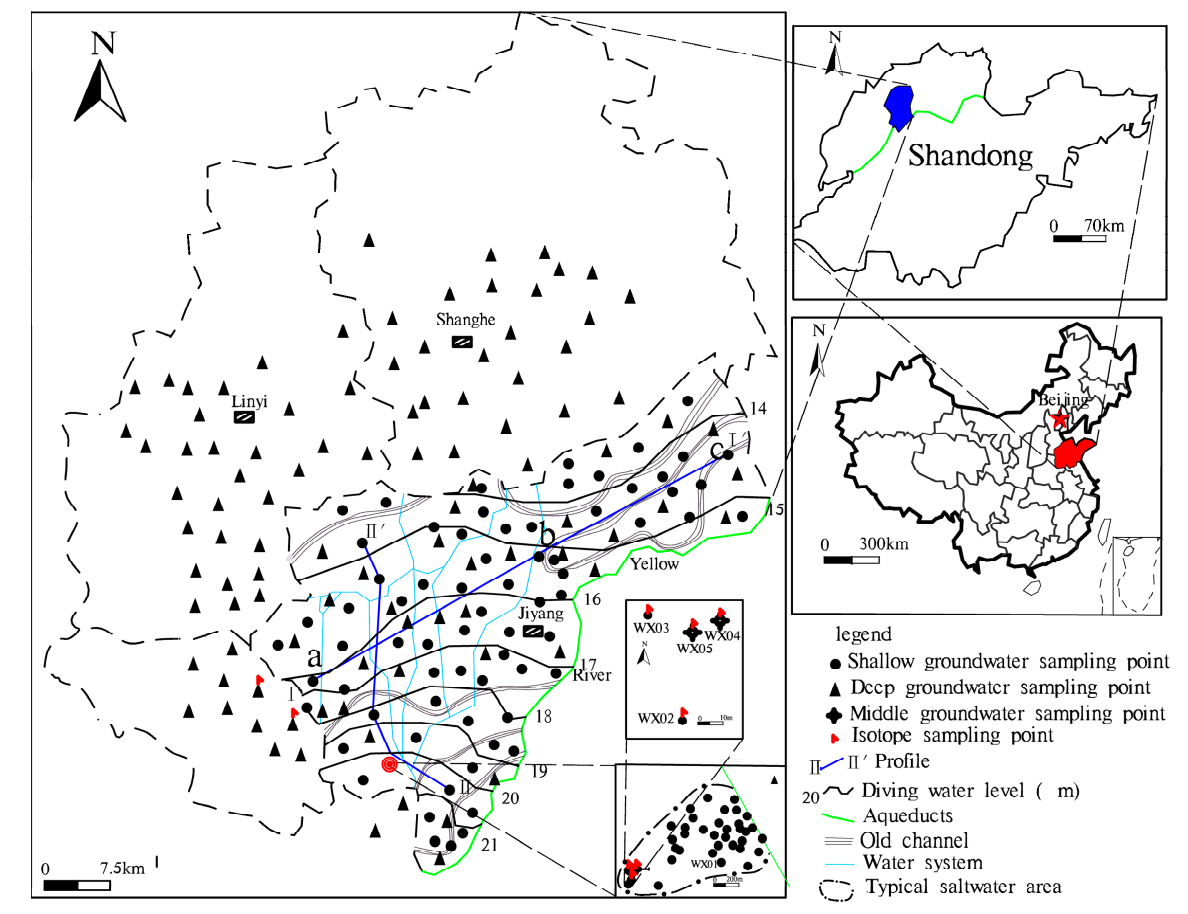

Figure 1. The sketch map of the groundwater flow field and the detection point in the study area. 


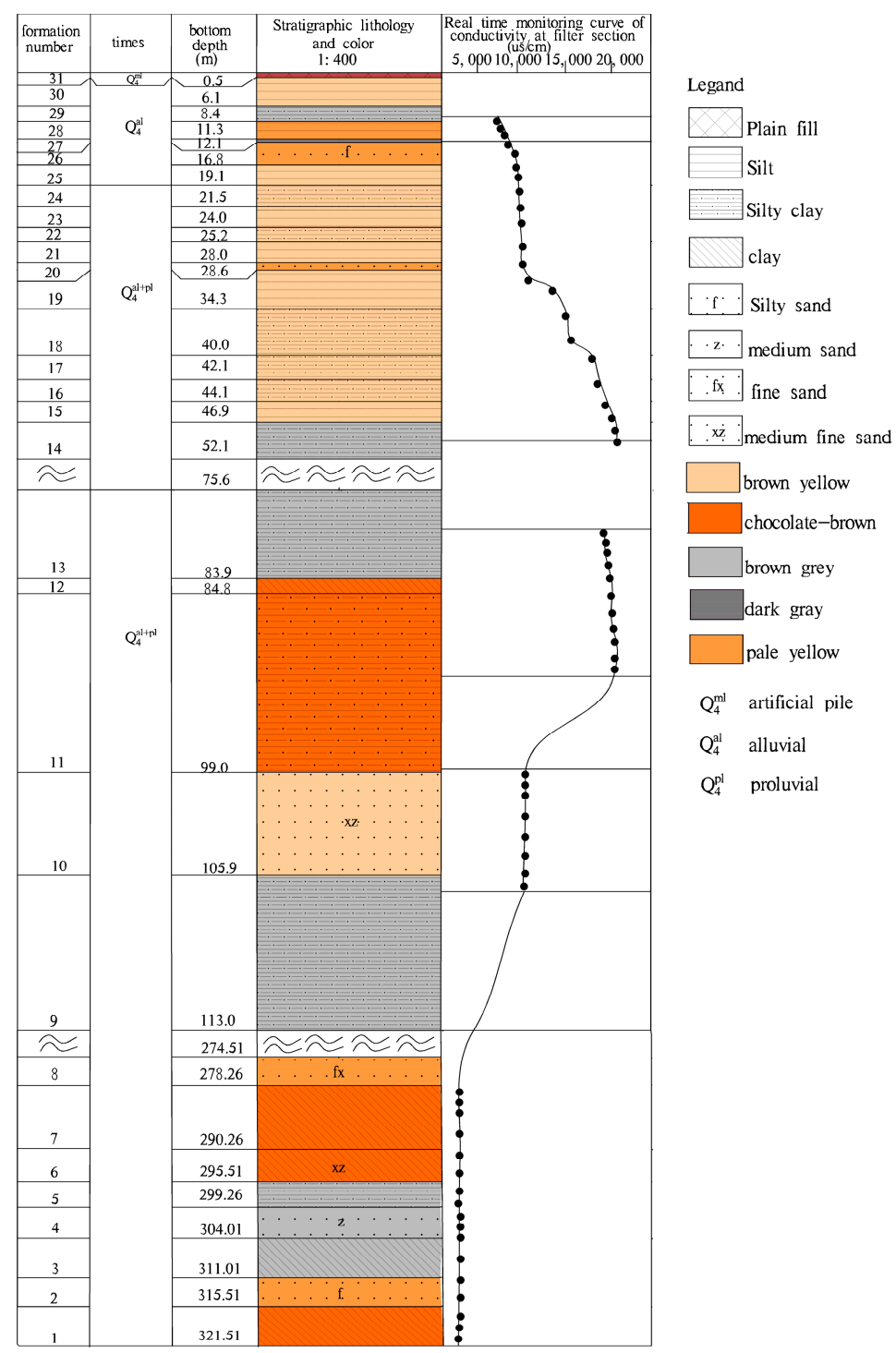

Figure 2. The shallow stratum histogram of a $321 \mathrm{~m}$ profile and groundwater conductivity at different depths.

\section{Materials and Methods}

\subsection{Collection and Testing of Groundwater Samples}

The hydrological survey was undertaken in the study area, resulting in the collection of 70 diving samples whose depth is less than $60 \mathrm{~m}$ (from an area of $1076 \mathrm{~km}^{2}$ in Jiyang County), including 30 samples in the dry period, 40 samples in the wet period and 101 deep groundwater samples whose depth is greater than $200 \mathrm{~m}$ in and around Jiyang County. At the same time, 20 shallow brackish water samples and 40 middle brackish water samples whose depth is between 60-200 m were collected in $3.2 \mathrm{~km}^{2}$ typical saltwater areas (Figure 1). Before taking the water sample, we rinsed the washed $50 \mathrm{~mL}$ sample bottle with freshwater three times and then sealed the water. ${ }^{14} \mathrm{C},{ }^{3} \mathrm{H}, \mathrm{CFC}-11, \mathrm{CFC}-12$ samples used a $60 \mathrm{~mL}$ glass bottle. Then, before sampling, the glass bottle was rinsed and stored in sealed conditions to avoid exposure to air. ${ }^{14} \mathrm{C},{ }^{3} \mathrm{H}, \mathrm{CFC}-11, \mathrm{CFC}-12$ samples were sent to the Beta Analytic Radiocarbon Dating Laboratory to complete the test [7]. $\mathrm{K}^{+}$and $\mathrm{Na}^{+}$were measured using a flame photometer and $\mathrm{Ca}^{2+}$ and $\mathrm{Mg}^{2+}$ were measured using a Shimadzu-AA7000 atomic absorption spectrophotometer. $\mathrm{SO}_{4}{ }^{2-}$ was determined using the EDTA-Mg titration method. $\mathrm{CO}_{3}{ }^{2-}, \mathrm{HCO}_{3}{ }^{-}$was 
determined using the acid-base titration method with methyl orange as the indicator. Titration of $\mathrm{Cl}^{-}$ used a potassium chromate indicator. Control samples and the relative balance of anion balance was within $\pm 5 \%$.

\subsection{Dynamic Monitoring of Groundwater}

In order to collect soil samples from different depths for adsorption analysis, coring techniques were used. After coring, six stratified observation holes were created (WX01-06; Table 1). Groundwater dynamic monitoring was undertaken over a two-year period to obtain the aquifer level and water quality data at different depths.

(1) Stratified monitoring of the groundwater level was undertaken at different depths in the observation holes on a weekly basis.

(2) Stratified monitoring of groundwater quality characteristics was undertaken at different depths using an Aqualtroll 600-type multi-parameter water quality detector. Conductivity (EC) changes from the top to the bottom of the profiles were recorded using a test interval of $1 \mathrm{~m}$. Test accuracy was $\pm 0.5 \%+1 \mu \mathrm{s} / \mathrm{cm}$. Weekly monitoring commenced in November, 2016.

Table 1. Basic parameters of typical test wells.

\begin{tabular}{cccccc}
\hline $\begin{array}{c}\text { Well } \\
\text { Number }\end{array}$ & $\begin{array}{c}\text { Well } \\
\text { Diameter/mm }\end{array}$ & $\begin{array}{c}\text { Well } \\
\text { Depth/m }\end{array}$ & $\begin{array}{c}\text { Filter Tube } \\
\text { Depth/m }\end{array}$ & $\begin{array}{c}\text { Groundwater } \\
\text { Level/m }\end{array}$ & Aquifer Lithology \\
\hline WX01 & 146 & 8 & $3-8$ & 23.59 & Silty clay \\
WX02 & 146 & 12 & $8-12$ & 21.03 & Silt \\
WX03 & 235 & 50 & $13-50$ & 20.99 & Silty clay \\
WX04 & 140 & 91 & $78-90$ & 19.16 & Silty clay \\
WX05 & 140 & 113 & $99-108$ & 18.26 & silty sand \\
WX06 & 180 & 336 & $274-333$ & 24.00 & Fine sand, fine sand, \\
& & & & medium sand \\
\hline
\end{tabular}

\subsection{Adsorption Isothermal Experiment}

\subsubsection{Experimental Procedure}

To examine the adsorption characteristics of clays at different depths to $\mathrm{Na}^{+}, \mathrm{Ca}^{2+}$ and $\mathrm{Mg}^{2+}$ in groundwater, the indoor adsorption isothermal batch method $[39,40]$ was used. For analysis, soil samples ( $3000 \mathrm{~g}$ ) were taken from different depths. All debris was removed and the samples were air dried. Samples were then sieved through a 20 mesh and oven dried. Samples were ground (using a mortar) and passed through a 100 mesh sieve and retained for the adsorption experiment.

A $30 \mathrm{~g}$ sub-sample of clay from different depth aquifers, obtained by drilling and which represents different aquifer media, was placed into a $250 \mathrm{~mL}$ Erlenmeyer flask. A $150 \mathrm{~mL}$ volume different concentration of water samples were added to the flasks, respectively, after which the flask was placed into water bath thermostatic shaker and shaken for $3 \mathrm{~h}$ until adsorption reached saturation. Samples were centrifuged at $4000 \mathrm{r} \cdot \mathrm{min}^{-1}$ for $1 \mathrm{~min}$ and filtered through a $0.45 \mu \mathrm{m}$ microporous membrane. $2 \mathrm{~mL}$ of the filtrate was then used to test for $\mathrm{Na}^{+}, \mathrm{Ca}^{2+}$ and $\mathrm{Mg}^{2+}$ concentrations (using atomic absorption spectrophotometer-AA7000). The experiment was repeated three times to obtain effective data of 307 groups.

\subsubsection{Calculation of the Retardation Coefficient}

The adsorption capacity of clay on groundwater $\mathrm{Na}^{+}, \mathrm{Ca}^{2+}$ and $\mathrm{Mg}^{2+}$ is indicated by adsorption capacity $Q_{e}$, and the adsorption efficiency is expressed by $\varepsilon$, the formula are (1) and (2):

$$
Q_{e}=\frac{\left(C_{0}-C_{e}\right) \times V}{m}
$$




$$
\varepsilon=\frac{\left(C_{0}-C_{e}\right)}{C_{0}} \times 100 \%
$$

The Temkin equation, Langmuir equation, Freundlich equation and Henry equation were used to fit the adsorption isotherms of $\mathrm{Na}^{+}, \mathrm{Ca}^{2+}$ and $\mathrm{Mg}^{2+}$ in the groundwater. The Temkin, Freundlich and Langmuir equations belong to the monolayer adsorption. The Henry equation is linear. Equation is (3)-(6) [42,43]:

$$
\begin{gathered}
Q_{e}=k \times \lg C_{e}+a \\
Q_{e}=\frac{K_{L} \times Q_{m} \times C_{e}}{1+K_{L} \times C_{e}} \\
Q_{e}=K_{F} \times C_{\mathrm{e}}{ }^{n} \\
Q_{e}=K_{d} \times C_{e}
\end{gathered}
$$

Clay effective porosity, $n_{e}$, was calculated according to Equation (7) and the retardation coefficient, $R_{d}$, was calculated according to Equation (8) [44,45]:

$$
\begin{gathered}
n_{e}=\frac{e_{0}}{1+e_{0}} \\
R_{d}=1+\frac{1-n}{n} K_{d}
\end{gathered}
$$

where $C_{0}$ is the initial concentration of conventional ions in groundwater, $\mathrm{mg} \cdot \mathrm{L}^{-1} ; C_{e}$ is the equilibrium concentration of adsorption, $\mathrm{mg} \cdot \mathrm{L}^{-1} ; Q_{e}$ is the adsorption capacity, $\mathrm{mg} \cdot \mathrm{kg}^{-1} ; V$ is the volume of the test water sample, $\mathrm{L} ; m$ is the volume of soil samples, $\mathrm{kg} ; K$ is the parameter of the Temkin equation and describes the conventional ionic strength of soil in the sample; $Q_{m}$ and $K_{L}$ are the maximum adsorption capacity and adsorption energy-related parameters for the Langmuir adsorption equation, $\mathrm{mg} \cdot \mathrm{kg}^{-1}$ and L. $\mathrm{mg}^{-1}$, respectively; $K_{F}$ is the Freundlich adsorption equation; $K_{d}$ is the partition coefficient of the Henry equation and describes the ratio of the conventional ion concentration in the clay to the concentration in the groundwater at adsorption equilibrium, $\mathrm{L} \cdot \mathrm{kg}^{-1} ; e_{0}$ is the porosity ratio, as determined by the geotechnical test; $n_{e}$ is the effective porosity; and $R_{d}$ is the retardation coefficient which characterizes the medium's ability to block solutes.

\section{Results and Discussion}

\subsection{Groundwater Chemical Composition and Zoning Characteristics}

\subsubsection{Chemical Characteristics of Shallow Groundwater}

Analysis of 70 groundwater samples in Jiyang County indicated that TDS of the shallow groundwater was between $0.55 \mathrm{~g} \cdot \mathrm{L}^{-1}$ and $13.10 \mathrm{~g} \cdot \mathrm{L}^{-1}$ (Table 2). Apart from individual water samples whose depths less than $10 \mathrm{~m}$ deep, there are almost no changes in the type of hydrochemistry and the content of various ions; although the total dissolved solids of water samples whose depths less than $10 \mathrm{~m}$ deep are larger during the dry season and smaller during the rainy season, there is no change in the type of hydrochemistry. Freshwater samples with TDS $<2 \mathrm{~g} \cdot \mathrm{L}^{-1}$ accounted for $74.3 \%$ of total samples, mainly accounting for $\mathrm{HCO}_{3}$-type water, such as the $\mathrm{HCO}_{3}-\mathrm{Na}(\mathrm{Mg} \cdot \mathrm{Na})$ type and the $\mathrm{HCO}_{3}$ $\left(\mathrm{HCO}_{3} \cdot \mathrm{Cl}\right)-\mathrm{Na} \cdot \mathrm{Mg}$ type. Brackish water with a TDS of $2-3 \mathrm{~g} \cdot \mathrm{L}^{-1}$ accounted for $15.7 \%$ of total samples. The major hydrochemical types were $\mathrm{Cl} \cdot \mathrm{HCO}_{3}\left(\mathrm{HCO}_{3} \cdot \mathrm{Cl}^{-} \mathrm{SO}_{4}, \mathrm{HCO}_{3} \cdot \mathrm{SO}_{4} \cdot \mathrm{Cl}\right)-\mathrm{Na} \cdot \mathrm{Mg}$ type, $\mathrm{HCO}_{3}-\mathrm{Na}$ $(\mathrm{Na} \cdot \mathrm{Mg})$ type and $\mathrm{HCO}_{3} \cdot \mathrm{SO}_{4}$-Na type. Brackish water with a TDS of $3-5 \mathrm{~g} \cdot \mathrm{L}^{-1}$ accounted for $8.6 \%$ of water samples, with $\mathrm{Cl} \cdot \mathrm{HCO}_{3}-\mathrm{Mg} \cdot \mathrm{Na} \cdot \mathrm{Ca}$ as the main type and $\mathrm{Cl} \cdot \mathrm{SO}_{4}-\mathrm{Na}(\mathrm{Na} \cdot \mathrm{Mg})$ as the secondary type. Saltwater with a TDS $>5 \mathrm{~g} \cdot \mathrm{L}^{-1}$ contained $\mathrm{Cl} \cdot \mathrm{SO}_{4}-\mathrm{Na} \cdot \mathrm{Mg}$ or $\mathrm{Cl} \cdot \mathrm{SO}_{4}-\mathrm{Mg} \cdot \mathrm{Na}$ types. The shallow groundwater $\mathrm{HCO}_{3}{ }^{-}$coefficient of variation was less and the $\mathrm{Cl}^{-}, \mathrm{SO}_{4}{ }^{2-}$ and $\mathrm{Na}^{+}$coefficient of variation was larger, indicting complex chemical types. 
Table 2. Unconfined common water chemical composition characteristic value $(n=70)$.

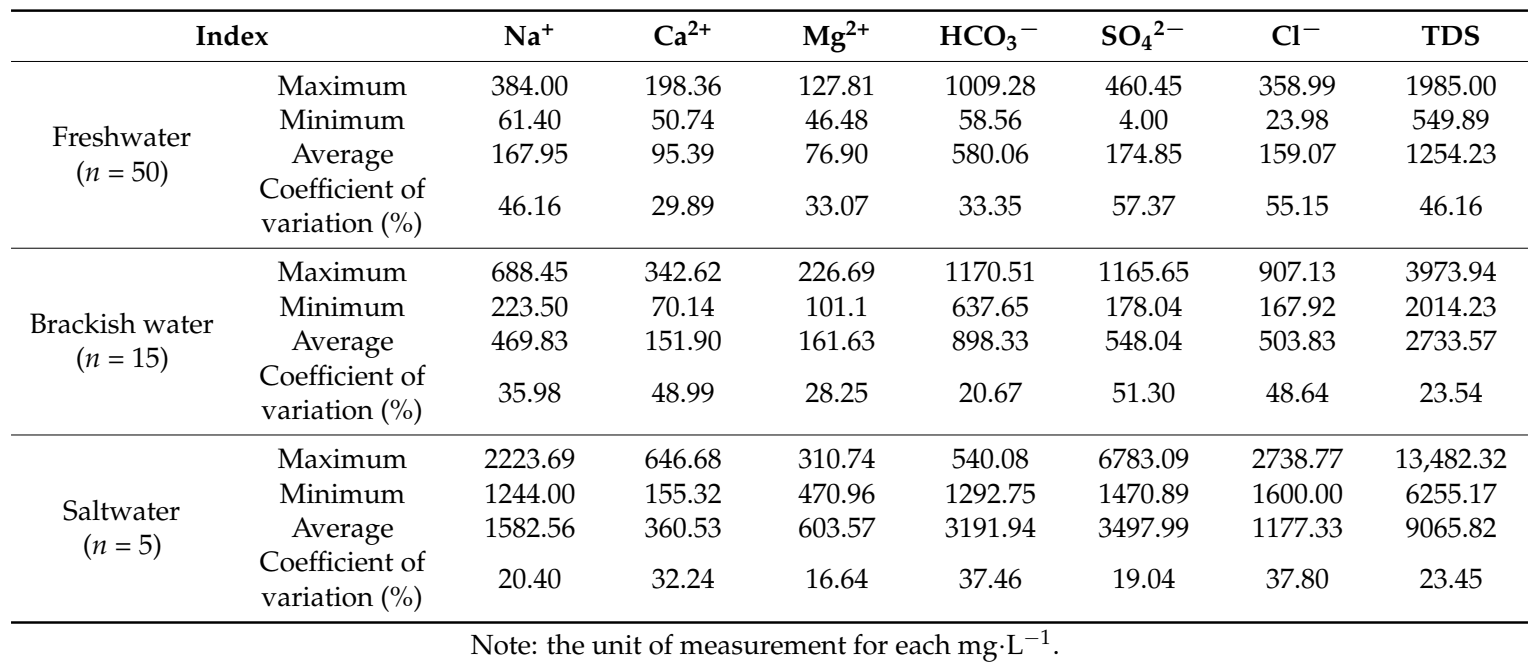

\subsubsection{Hydrochemical Types and Horizontal Zoning Characteristics}

Shallow groundwater hydrochemical types reflect a certain level of zonation.

(1) Groundwater flow from the Southwest to the Northeast. The longer migration route, the greater the TDS of the groundwater. In Section I, Fengjiajing Village in Taiping Town (a located in the Southwest) - Hujiacun (b located in the Central)_-Tanjia Village in Renfeng Town (c located in the Northeast) (Figure 1) of Taiping Town, groundwater was changed from freshwater with a TDS $<1 \mathrm{~g} \cdot \mathrm{L}^{-1}$ to brackish water with a TDS $>3 \mathrm{~g} \cdot \mathrm{L}^{-1} \cdot \mathrm{Na}^{+}, \mathrm{Ca}^{2+}, \mathrm{Mg}^{2+}, \mathrm{Cl}^{-}, \mathrm{HCO}_{3}{ }^{-}, \mathrm{SO}_{4}{ }^{2-}$ and TDS all recorded a gradual increase. The hydrochemistry types were $\mathrm{HCO}_{3}-\mathrm{Na} \cdot \mathrm{Mg} \rightarrow \mathrm{HCO}_{3} \cdot \mathrm{Cl}$ $\cdot \mathrm{SO}_{4}-\mathrm{Na} \cdot \mathrm{Mg} \rightarrow \mathrm{Cl} \cdot \mathrm{HCO}_{3}-\mathrm{Na} \cdot \mathrm{Mg}$ (Figure 4 ).

(2) Brackish water and freshwater show an alternate distribution in local areas. Groundwater with a high salinity had a sporadic or irregular strip-shaped distributing interfluve between old channels (Figure 3). There are numerous seasonal streams and diversion channels in the Jiyang surface water system. Freshwater with a TDS $<2 \mathrm{~g} \cdot \mathrm{L}^{-1}$ is mainly distributed along the Yellow River, along the Tuhai River, near the Dasi River and around the Heishi River. The main hydrochemistry type is $\mathrm{HCO}_{3}$ type. The brackish water-saltwater area is mainly distributed between river, showing north-easterly. This area recorded a general TDS $>3 \mathrm{~g} \cdot \mathrm{L}^{-1}$, with results occasionally being $>5 \mathrm{~g} \cdot \mathrm{L}^{-1}$. TDS samples in the Old Tang Temple were recorded to be $>10 \mathrm{~g} \cdot \mathrm{L}^{-1}$. In the direction of Section II, the hydrochemistry types were $\mathrm{HCO}_{3} \cdot \mathrm{Cl}-\mathrm{Mg} \cdot \mathrm{Na} \cdot \mathrm{Ca}$, $\mathrm{Cl} \cdot \mathrm{SO}_{4}-\mathrm{Mg} \cdot \mathrm{Na} \cdot \mathrm{Ca}, \mathrm{HCO}_{3} \cdot \mathrm{Cl}-\mathrm{Mg} \cdot \mathrm{Na}$ and $\mathrm{HCO}_{3} \cdot \mathrm{Cl}-\mathrm{Mg} \cdot \mathrm{Na}, \mathrm{Cl} \cdot \mathrm{SO}_{4}-\mathrm{Na} \cdot \mathrm{Mg}$ type, formed a freshwater-saltwater-freshwater-saltwater pattern. 


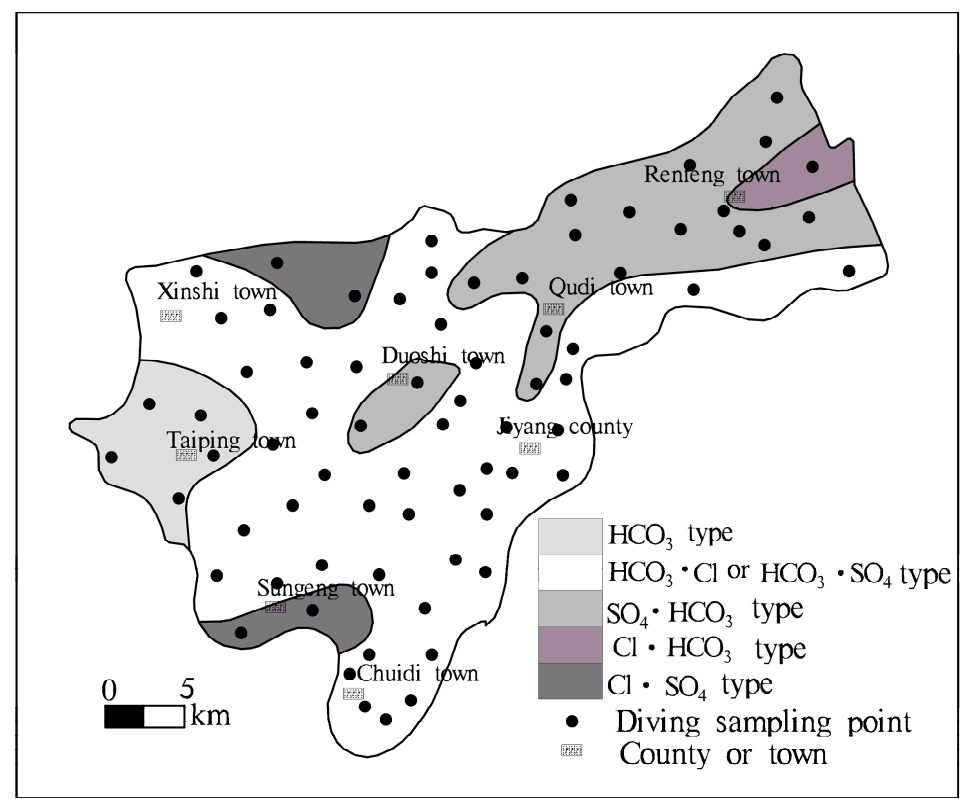

Figure 3. Sketch map of horizontal hydrochemical zonation of phreatic water in the study area.

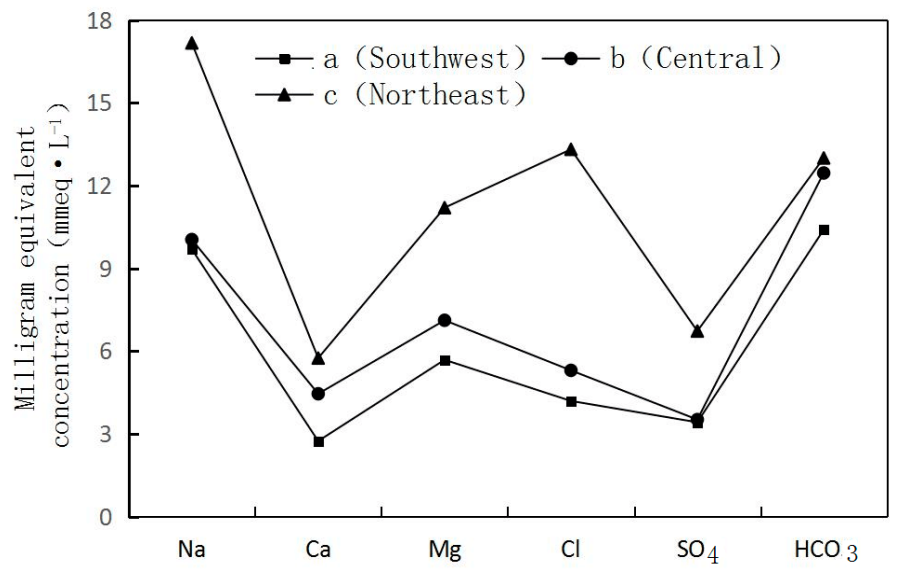

Figure 4. Variation trend of the shallow groundwater component.

\subsection{Groundwater Chemical Composition of the Vertical Zone Characteristics}

\subsubsection{Changes in the Chemical Composition of Saltwater with Depth}

Taking Sungeng town as a case-study, the distribution area of shallow saltwater was $1.41 \mathrm{~km}^{2}$, $\mathrm{pH}$ ranged from $6.96-7.11$, TDS $>10 \mathrm{~g} \cdot \mathrm{L}^{-1}$, and the order of cations (by average concentration) was: $\mathrm{Na}^{+}\left(2029.10 \mathrm{mg} \cdot \mathrm{L}^{-1}\right)>\mathrm{Ca}^{2+}\left(798.65 \mathrm{mg} \cdot \mathrm{L}^{-1}\right)>\mathrm{Mg}^{2+}\left(791.81 \mathrm{mg} \cdot \mathrm{L}^{-1}\right)$. The order of anions (by average concentration) was: $\mathrm{Cl}^{-}\left(3791.59 \mathrm{mg} \cdot \mathrm{L}^{-1}\right)>\mathrm{SO}_{4}{ }^{2-}\left(3251.69 \mathrm{mg} \cdot \mathrm{L}^{-1}\right)>\mathrm{HCO}_{3}{ }^{-}(886.96$ $\mathrm{mg} \cdot \mathrm{L}^{-1}$ ) (Table 3). Due to differences in burial conditions, the $\mathrm{pH}$ value of the middle saltwater ranged from 7.01-8.16, this being weakly alkaline. Average results for cations and anions were: $\mathrm{Na}^{+}$ $\left(2108.01 \mathrm{mg} \cdot \mathrm{L}^{-1}\right)>\mathrm{Mg}^{2+}\left(714.79 \mathrm{mg} \cdot \mathrm{L}^{-1}\right)>\mathrm{Ca}^{2+}\left(670.10 \mathrm{mg} \cdot \mathrm{L}^{-1}\right)$ and $\mathrm{SO}_{4}{ }^{2-}\left(3266.29 \mathrm{mg} \cdot \mathrm{L}^{-1}\right)>$ $\mathrm{Cl}^{-}\left(2865.51 \mathrm{mg} \cdot \mathrm{L}^{-1}\right)>\mathrm{HCO}_{3}{ }^{-}\left(244.71 \mathrm{mg} \cdot \mathrm{L}^{-1}\right)$, respectively. Due to ground subsidence caused by deep groundwater exploitation, the deep production wells in Jiyang have been closed. Sampling and analysis in the surrounding counties indicates that TDS of deep pressure water is less than $3 \mathrm{~g} \cdot \mathrm{L}^{-1}$, and the highest cation concentration $\left(\mathrm{Na}^{+}\right)$was $345.29 \mathrm{mg} \cdot \mathrm{L}^{-1}$. Results for $\mathrm{HCO}_{3}{ }^{-}, \mathrm{Cl}^{-}$and $\mathrm{SO}_{4}{ }^{2-}$ were $429.08 \mathrm{mg} \cdot \mathrm{L}^{-1}, 247.64 \mathrm{mg} \cdot \mathrm{L}^{-1}$ and $205.99 \mathrm{mg} \cdot \mathrm{L}^{-1}$, respectively. Therefore, vertical distribution of groundwater have obvious zonation characteristics in this area. 
Table 3. Characteristic values of conventional hydrochemical composition of groundwater $(n=141)$.

\begin{tabular}{|c|c|c|c|c|c|c|c|c|c|}
\hline \multicolumn{2}{|c|}{ Index } & $\mathrm{Na}^{+}$ & $\mathrm{Ca}^{2+}$ & $\mathrm{Mg}^{2+}$ & $\mathrm{HCO}_{3}{ }^{-}$ & $\mathrm{SO}_{4}^{2-}$ & $\mathrm{Cl}^{-}$ & PH & TDS \\
\hline \multirow{4}{*}{$\begin{array}{c}\text { Shallow salt } \\
\text { water }(n=20)\end{array}$} & Maximum & 4201.20 & 1062.51 & 1022.00 & 1183.8 & 6494.00 & 5321.24 & 7.11 & $16,984.20$ \\
\hline & Minimum & 1094.24 & 264.47 & 283.21 & 645.54 & 1877.40 & 1217.00 & 6.99 & 5242.40 \\
\hline & Average & 2029.10 & 798.65 & 791.81 & 886.96 & 3251.69 & 3791.59 & 7.04 & $10,077.96$ \\
\hline & $\begin{array}{l}\text { Coefficient of } \\
\text { variation }(\%)\end{array}$ & 41.82 & 25.67 & 37.79 & 12.28 & 27.32 & 32.98 & 1.09 & 26.05 \\
\hline \multirow{4}{*}{$\begin{array}{c}\text { Middle } \\
\text { confined } \\
\text { water }(n=20)\end{array}$} & Maximum & 2250.16 & 879.25 & 853.25 & 318.14 & 3266.29 & 3616.50 & 8.16 & $13,482.32$ \\
\hline & Minimum & 1088.18 & 395.33 & 336.75 & 192.37 & 849.09 & 849.09 & 7.01 & 5572.77 \\
\hline & Average & 2108.01 & 545.05 & 560.93 & 244.71 & 3266.29 & 2865.51 & 7.59 & 8991.46 \\
\hline & $\begin{array}{l}\text { Coefficient of } \\
\text { variation }(\%)\end{array}$ & 29.32 & 25.35 & 29.83 & 17.92 & 58.11 & 9.09 & 4.87 & 31.04 \\
\hline \multirow{4}{*}{$\begin{array}{c}\text { Deep } \\
\text { freshwater } \\
(n=101)\end{array}$} & Maximum & 970.00 & 125.16 & 110.99 & 540.08 & 1274.01 & 1036.32 & 1 & 3339.83 \\
\hline & Minimum & 11.00 & 5.18 & 1.36 & 186.20 & 16.97 & 21.52 & 1 & 372.72 \\
\hline & Average & 345.29 & 27.59 & 23.74 & 429.08 & 205.99 & 247.64 & 1 & 1285.15 \\
\hline & $\begin{array}{l}\text { Coefficient of } \\
\text { variation }(\%)\end{array}$ & 34.59 & 91.56 & 76.67 & 26.15 & 74.87 & 59.03 & 1 & 28.21 \\
\hline
\end{tabular}

Note: In addition to $\mathrm{pH}$, the unit of measurement for each $\mathrm{mg} \cdot \mathrm{L}^{-1}$. Deep freshwater was not $\mathrm{pH}$ real-time monitored.

\subsubsection{Groundwater Conductivity with Depth}

Long-term monitoring results (2016-2017) indicate that groundwater from similar depths have similar conductivity values, and conductivity depths greater than $10 \mathrm{~m}$ are relatively stable. The variation amplitude between samples at the same depth was around $1.5 \mathrm{~ms} / \mathrm{cm}$ (Figure $5 \mathrm{a}$ ). There is a change in vertical conductivity at different depths, (Figure 5b). The rainfall recharge [7] had a significant effect on conductivity depth less than $10 \mathrm{~m}$. With the increase of depth, the effect of low conductivity rainwater mixing was weaker, and with vertical conductivity gradually increasing from $8088 \mu \mathrm{s} / \mathrm{cm}$, the rate of increase was $254 \mu \mathrm{s} / \mathrm{cm}$ per meter. Conductivity between 11-28 m and 28-45 m were relatively stable. At $45 \mathrm{~m}$, conductivity abruptly increased to $20,699 \mu \mathrm{s} / \mathrm{cm}$ before decreasing. Conductivity from 70-76 m was again relatively stable $(18,621 \mu \mathrm{s} / \mathrm{cm})$. From $82-89 \mathrm{~m}$, conductivity increased slightly with depth (to $19,758 \mu \mathrm{s} / \mathrm{cm}$ ). After $100 \mathrm{~m}$ a final sudden decline was recorded, with conductivity stabilizing around $12,019 \mu \mathrm{s} / \mathrm{cm}$.

According to the core observation, gypsum crystals (maximum crystal length of $5 \mathrm{~cm}$ ) are occasionally present in clays and silty clays at a depth of 45 to $90 \mathrm{~m}$, and the maximum crystal length is $5 \mathrm{~cm}$. The graded and abrupt change of groundwater conductance in the vertical direction reflects that the formation of clay in different sedimentary environments has a significant influence on vertical zoning of groundwater conductivity.

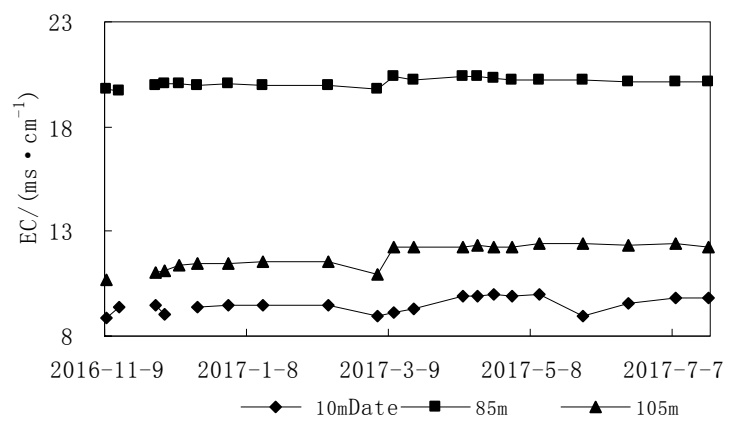

(a)

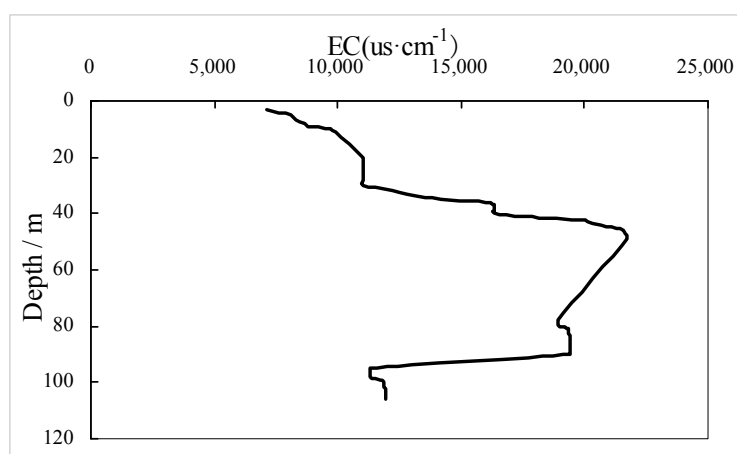

(b)

Figure 5. The conductivity and dynamic diagram of groundwater of different depths (a) Dynamic curve of electrical conductivity at different depths; (b) Vertical conductivity distribution diagram of vertical depth). 


\subsubsection{Groundwater Hydrochemical Vertical Zoning Characteristics}

According to the Shukalev classification, shallow saltwater was dominated by $\mathrm{Mg}^{2+}, \mathrm{Na}^{+}$ and $\mathrm{Ca}^{2+}$ salts and $\mathrm{Cl}^{-}$and $\mathrm{SO}_{4}{ }^{2-}$ anions. The coefficients of variation of $\mathrm{Mg}^{2+}, \mathrm{Na}^{+}$and $\mathrm{Cl}^{-}$are small. The hydrochemistry type of the saltwater was $\mathrm{Cl} \cdot \mathrm{SO}_{4}-\mathrm{Mg} \cdot \mathrm{Na} \cdot \mathrm{Ca}$ type and the individual is $\mathrm{Cl} \cdot \mathrm{SO}_{4}-\mathrm{Na} \cdot \mathrm{Mg} \cdot \mathrm{Ca}$ type. Cations in the middle brackish water were mainly $\mathrm{Na}^{+}$ and $\mathrm{Mg}^{2+}$, with the main anions being $\mathrm{SO}_{4}{ }^{2-}$ and $\mathrm{Cl}^{-}$. The coefficient of variation of $\mathrm{SO}_{4}{ }^{2-}$ was larger and the remainder of the conventional ion coefficient of variation was less. The main hydrochemistry types were $\mathrm{SO}_{4} \cdot \mathrm{Cl}-\mathrm{Na} \cdot \mathrm{Mg}$ and $\mathrm{Cl} \cdot \mathrm{SO}_{4}-\mathrm{Mg} \cdot \mathrm{Na}$. Hydrochemistry types of deep confined water were the $\mathrm{HCO}_{3}$ type, such as $\mathrm{HCO}_{3}-\mathrm{Na}, \mathrm{HCO}_{3} \cdot \mathrm{Cl}\left(\mathrm{HCO}_{3} \cdot \mathrm{SO}_{4} \cdot \mathrm{Cl}, \mathrm{HCO}_{3} \cdot \mathrm{Cl} \cdot \mathrm{SO}_{4}\right)-\mathrm{Na}$ and $\mathrm{Cl} \cdot \mathrm{HCO}_{3} \cdot \mathrm{SO}_{4}-\mathrm{Na}, \mathrm{HCO}_{3}-\mathrm{Ca} \cdot \mathrm{Mg}$. The coefficient of variation for $\mathrm{HCO}_{3}{ }^{-}$and $\mathrm{Na}^{+}$was small. The vertical distribution of groundwater (depth less than $500 \mathrm{~m}$ ) can be divided into: shallow freshwater-middle saltwater-deep freshwater; shallow brackish water-middle saltwater-deep freshwater; and shallow saltwater-middle saltwater-deep freshwater. Shallow saltwater in Sungeng town often has no clear boundary with the mid-level saltwater, and the groundwater hydrochemical type is $\mathrm{Cl} \cdot \mathrm{SO}_{4}$ or $\mathrm{SO}_{4} \cdot \mathrm{Cl}$. Hydrological and geochemical characteristics of confined water in Yinchuan area are similar to those in the study area [18].

\subsection{Inland Plain Groundwater Mechanisms}

\subsubsection{Groundwater Characteristics}

The Piper trilinear nomograph (Figure 6) shows that there is a difference in the hydrochemical characteristics between shallow and deep confined water. Shallow groundwater receiving recharge of atmospheric precipitation is mainly dominated by leaching and the filtration effect. Saltwater samples are located in the I and IV districts of the Piper trilinear nomograph, reflecting evaporation, concentration and cation exchange during geological history. Deep confined water samples are mainly located in the II district, reflecting cation exchange, while shallow water samples in the lower half of the II district are only $2.8 \%$ (Figure 6).

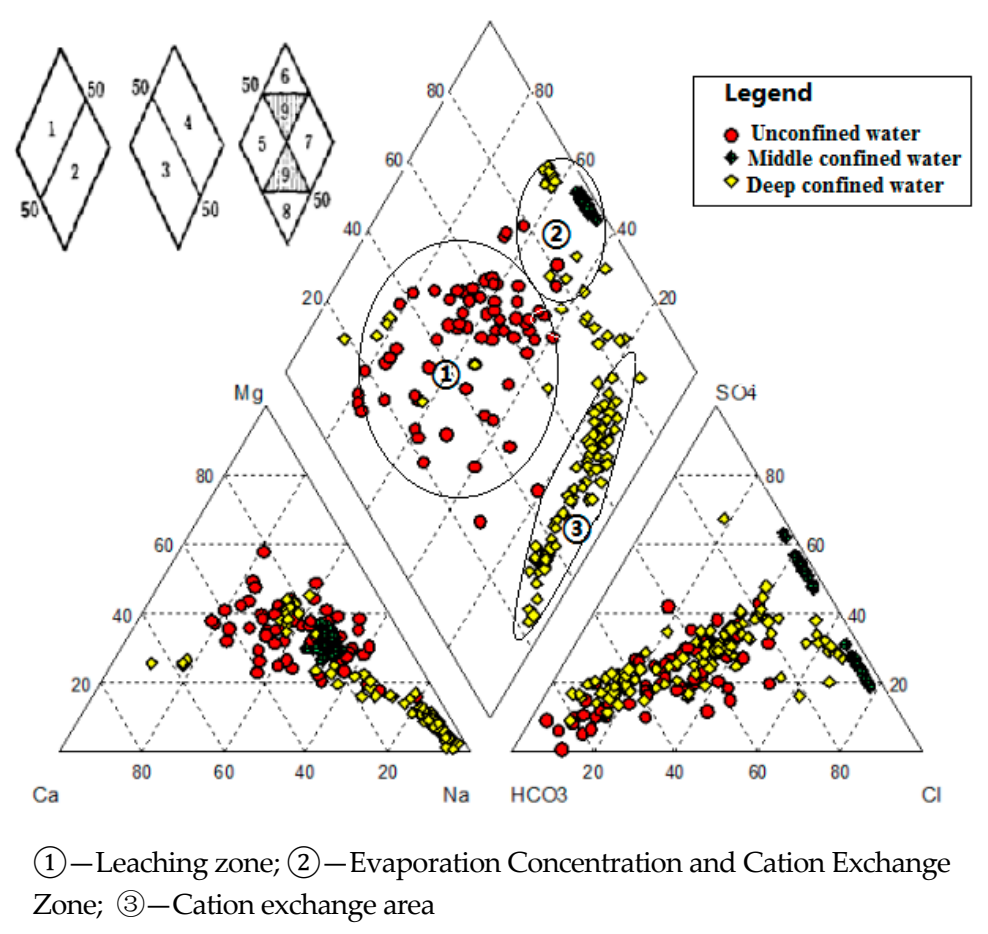

Figure 6. The Piper diagram for shallow unconfined water, middle confined water and deep confined water. 


\subsubsection{Effect of Clay Retarding Action on Chemical Zoning in Water}

(1) Isothermal adsorption equation

Clay plays a controlling role in the hydrodynamic field of a groundwater system. Clay formed in different depositional environments also has an impact on the chemical composition of groundwater. Adsorption experiments can therefore be used to investigate the effect of clay retardation on the chemical composition of water. $\mathrm{Na}^{+}, \mathrm{Ca}^{2+}$ and $\mathrm{Mg}^{2+}$ results from adsorption experiments were fitted with the Temkin, Langmuir, Freundlich and Henry adsorption isotherm equations. The optimal isothermal adsorption curves for $\mathrm{Na}^{+}, \mathrm{Ca}^{2+}$ and $\mathrm{Mg}^{2+}$ in groundwater with different depths clay were well fitted with the Henry and Langmuir equations (Table 4). Fitting results of the Temkin and Freundlich equations were not as suitable. Clay adsorption of $\mathrm{Na}^{+}, \mathrm{Ca}^{2+}$ and $\mathrm{Mg}^{2+}$ in groundwater has a monolayer or linear adsorption process [36].

The fitting results of the Langmuir adsorption isotherm equation show that the maximum adsorption capacity of clay to groundwater is different. For example, the order of the conventional ion adsorption capacity of groundwater with a depth of 6-6.2 $\mathrm{m}$ was $\mathrm{Ca}^{2+}>\mathrm{Mg}^{2+}>\mathrm{Na}^{+}$. The order of routine ion adsorption of clay to groundwater at a depth of 51-51.2 $\mathrm{m}$ was: $\mathrm{Na}^{+}>\mathrm{Mg}^{2+}>\mathrm{Ca}^{2+}$, and at a depth of 71-71.2 $\mathrm{m}$ the order of conventional ion adsorption of clay to groundwater was: $\mathrm{Mg}^{2+}>$ $\mathrm{Ca}^{2+}>\mathrm{Na}^{+}$. At depths of 84-84.2 m, 102-102.2 $\mathrm{m}$ and 112-112.2 m, ion adsorption was in the order of: $\mathrm{Mg}^{2+}>\mathrm{Na}^{+}>\mathrm{Ca}^{2+}$ (Table 4). In addition, Henry equation $K_{d}$ is the linear distribution coefficient [37]. The larger the $K_{d}$ value, the stronger the clay adsorption capacity. The order of clay $K_{d}$ values of the same depth fitted by the Henry model were in accordance with the order of the maximum adsorption capacity from the Langmuir equation. The maximum adsorption capacity of $\mathrm{Na}^{+}, \mathrm{Ca}^{2+}$ and $\mathrm{Mg}^{2+}$ is different in the same depth clays. The maximum adsorption capacity of the same ions is also different in various depth clays (Table 4).

Table 4. The adsorption isotherm model fitting parameters of different clay depth adsorptions for $\mathrm{Na}^{+}$, $\mathrm{Ca}^{2+}$ and $\mathrm{Mg}^{2+}$ in the groundwater.

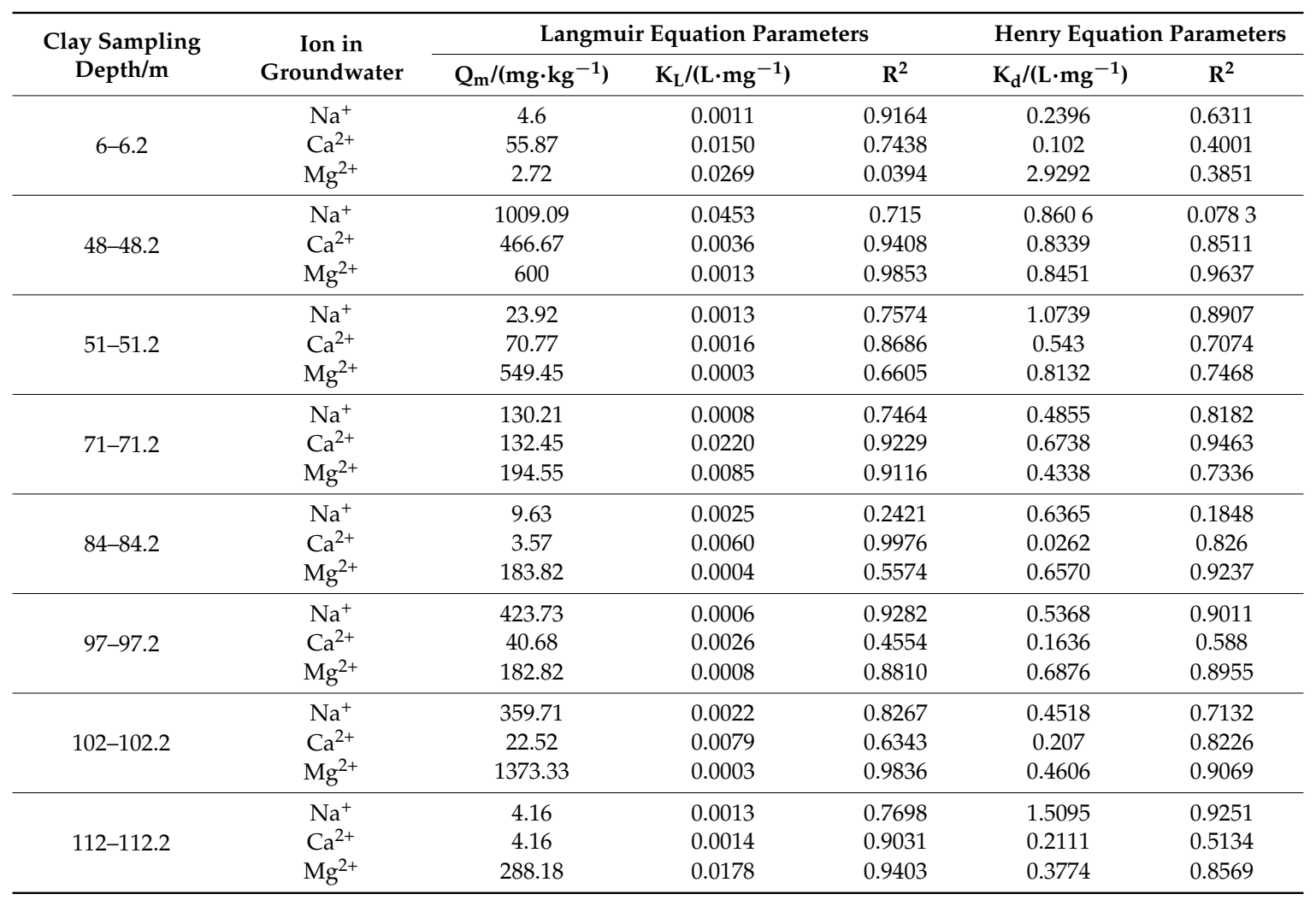


(2) Clay blocking effect

The blocking strength of clay in $\mathrm{Na}^{+}, \mathrm{Ca}^{2+}$ and $\mathrm{Mg}^{2+}$ in groundwater was expressed as the retardation coefficient $\mathrm{R}_{\mathrm{d}}$. The retardation coefficients of $\mathrm{Na}^{+}, \mathrm{Ca}^{2+}$ and $\mathrm{Mg}^{2+}$ in groundwater, calculated in Equations (7) and (8), show that the order of the conventional ion blockages of groundwater with depths of $6 \mathrm{~m}, 84 \mathrm{~m}, 97 \mathrm{~m}$ and $102 \mathrm{~m}$ was $\mathrm{Mg}^{2+}>\mathrm{Na}^{+}>\mathrm{Ca}^{2+}$. Groundwater with depths of $48 \mathrm{~m}$ and $112 \mathrm{~m}$ had a conventional ion block strength order of: $\mathrm{Na}^{+}>\mathrm{Mg}^{2+}>\mathrm{Ca}^{2+}$. The order of the conventional ion block strength of groundwater with a depth of $51.2 \mathrm{~m}$ was $\mathrm{Na}^{+}>$ $\mathrm{Ca}^{2+}>\mathrm{Mg}^{2+}$, and the order of the conventional ionic blockages of clay to groundwater at the depth of $71.2 \mathrm{~m}$ was: $\mathrm{Ca}^{2+}>\mathrm{Na}^{+}>\mathrm{Mg}^{2+}$ (Table 5). Results from these equations indicated that clays at the same depth have different retardation strengths for different conventional ions in groundwater. The blocking strength of clay at different depths for $\mathrm{Ca}^{2+}, \mathrm{Mg}^{2+}$ and $\mathrm{Na}^{+}$in groundwater varied alternately, reflecting that the sedimentary environment has a certain impact on the quality of the groundwater [40].

Table 5. The retardation coefficient of $\mathrm{Na}^{+}, \mathrm{Ca}^{2+}$ and $\mathrm{Mg}^{2+}$ in groundwater in cohesive soils of different depths.

\begin{tabular}{ccccc}
\hline Clay Sampling Depth/m & $\mathbf{R}_{\mathbf{d}-\mathbf{N a}}$ & $\mathbf{R}_{\mathbf{d}-\mathrm{Ca}}$ & $\mathbf{R}_{\mathbf{d}-\mathbf{M g}}$ & $\mathbf{R}_{\mathbf{d}-\text { sum }}$ \\
\hline 6 & 1.247 & 1.105 & 4.026 & 6.378 \\
48 & 2.594 & 2.544 & 2.565 & 7.703 \\
51 & 2.994 & 2.008 & 2.510 & 7.513 \\
71 & 1.902 & 2.251 & 1.806 & 5.959 \\
84 & 2.182 & 1.101 & 2.220 & 5.504 \\
97 & 1.997 & 1.304 & 2.277 & 5.578 \\
102 & 1.839 & 1.384 & 1.855 & 5.079 \\
112 & 3.803 & 1.392 & 1.701 & 6.896 \\
\hline
\end{tabular}

By comparing the clay retardation strength of different depths with the corresponding chemical composition of the groundwater, the correlation between the total retardation of $\mathrm{Na}^{+}, \mathrm{Ca}^{2+}, \mathrm{Mg}^{2+}$ and groundwater TDS from corresponding depths was calculated (Figure 7). The relationship between total retardation and groundwater TDS was calculated using the following equation:

$$
y=4818.3 x-9496\left(R^{2}=0.9167\right)
$$

where, $x$ was total retardation strength (a dimensionless value); and $y$ was total dissolved solids, $\mathrm{mg} \cdot \mathrm{L}^{-1}$.

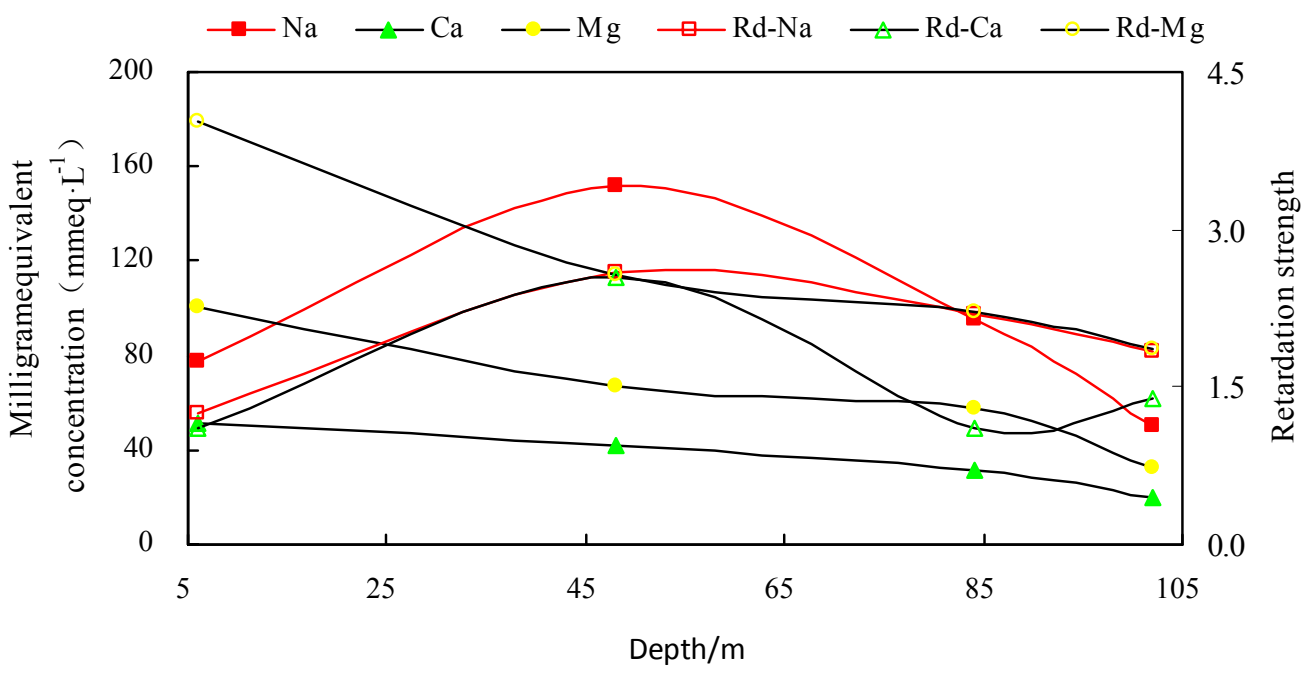

Figure 7. Variation trend of ion content and retardation coefficient of clay at different depths. 
The clay block in the hinterland plain area has some control over the vertical ion composition of groundwater, and that clay retardation plays a certain role in promoting $\mathrm{Na} \cdot \mathrm{Mg}$; $\mathrm{Mg} \cdot \mathrm{Na}$ saltwater (Figure 7).

\subsubsection{Groundwater Hydrogeochemistry Reflected in the Ion Ratio Coefficient}

(1) The role of leaching processes in shallow freshwater

$\gamma \mathrm{Na} / \gamma \mathrm{Cl}$ can be used to indicate the hydrogeochemical parameters of $\mathrm{Na}^{+}$enrichment in groundwater. Near the southern part of the study area and regions near the river, $\gamma \mathrm{Na} / \gamma \mathrm{Cl}$ from 1 to 2 accounts for $55.7 \%$ of the total, indicating that the groundwater is affected by the leaching effect $[7,26]$. The results of the study are similar to those in Northwestern Shandong [7].

(2) Strong saltwater cation exchange

As well as determining the intensity of ion exchange reactions in water chemistry, the $\gamma \mathrm{Ca} / \gamma \mathrm{Na}$ and $\gamma \mathrm{Mg} / \gamma \mathrm{Na}$ coefficients can also characterize the evolution of water quality and mineralization strength [7]. $\gamma \mathrm{Na} / \gamma \mathrm{Cl}$ of the shallow brackish water in the study area ranged from $0.5-0.6 ; \gamma \mathrm{Na} / \gamma \mathrm{Cl}$ in the middle confined aquifer ranged from $0.45-0.8$; and the ration in the deep confined water was greater than 3. The higher $\gamma \mathrm{Na} / \gamma \mathrm{Cl}$ corresponds to the lower $\gamma \mathrm{Mg}$ and $\gamma \mathrm{Ca}$ (Figure 8). $\gamma \mathrm{Mg} / \gamma \mathrm{Na}>$ $1, \gamma \mathrm{Ca} / \gamma \mathrm{Na}<1$, and $\mathrm{Mg}^{2+}$ in the saltwater zone were dominant, followed by $\mathrm{Na}^{+}$and $\mathrm{Ca}^{2+}$. Results indicate that the formation mechanism of deep confined freshwater, middle confined saltwater and shallow saltwater differed. The cation exchange activity in the saltwater area was stronger than that in the freshwater; $\mathrm{Ca}^{2+}$ and $\mathrm{Mg}^{2+}$ in middle and deep groundwater may have undergone cation exchange with $\mathrm{Na}^{+}$, which may have certain reference significance for the evolution of groundwater in other regions.

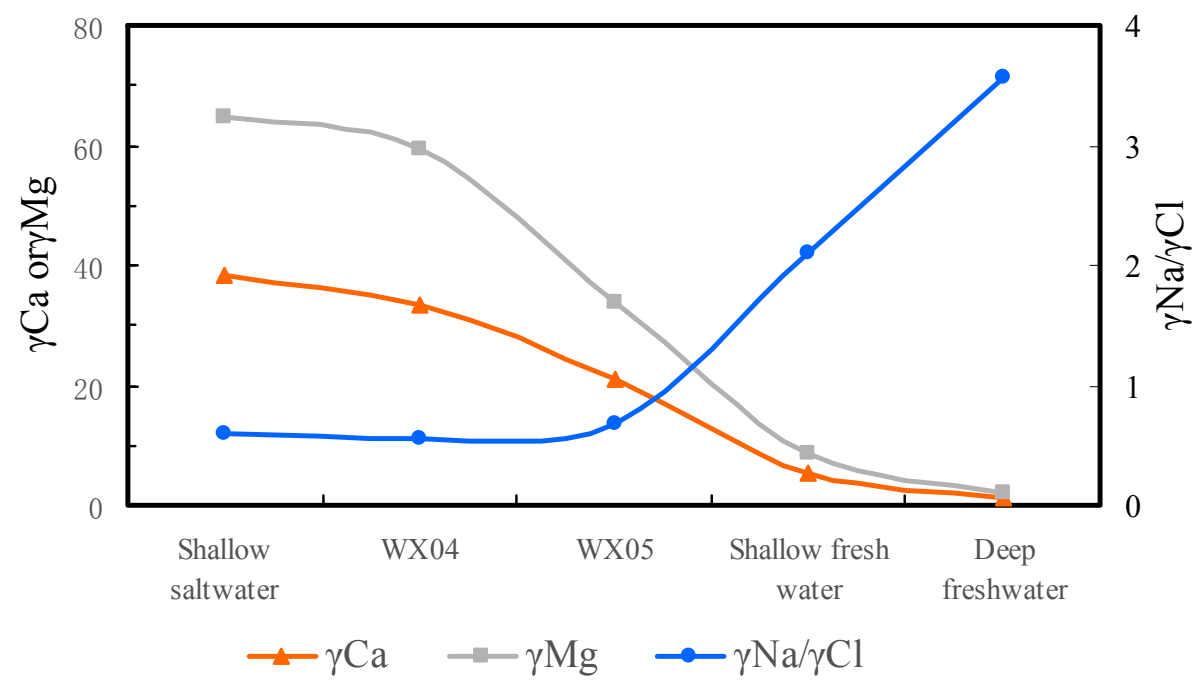

Figure 8. $\gamma \mathrm{Mg}, \gamma \mathrm{Ca}$ and $\gamma \mathrm{Na} / \gamma \mathrm{Cl}$ for different types of groundwater.

(3) Slow saltwater groundwater runoff rates

The $\gamma \mathrm{Ca} / \gamma \mathrm{Cl}$ ratio can be used to describe hydrodynamic conditions [11]. When TDS $<1.2 \mathrm{~g} \cdot \mathrm{L}^{-1}$, $\gamma \mathrm{Ca} / \gamma \mathrm{Cl}>2$ indicates favorable shallow groundwater runoff conditions. Saltwater TDS values in Sungeng town were $>3 \mathrm{~g} \cdot \mathrm{L}^{-1}$, and the $\gamma \mathrm{Ca} / \gamma \mathrm{Cl}$ ratio ranged from $0.2-0.4 . \mathrm{Cl}^{-}$enrichment indicated that its hydrodynamic conditions were very poor, this being the conditions consistent with a small hydraulic gradient and slow runoff in the study area [7]. The coefficients of $\gamma \mathrm{HCO}_{3} / \gamma \mathrm{SO}_{4}$ and $\gamma \mathrm{HCO}_{3} / \gamma \mathrm{Cl}$ in the saltwater area were both less than 1 , indicating that the saltwater area is affected by evaporite dissolution [26], which is helpful to ionic composition analysis in other regions. The average 
value of the $\gamma \mathrm{HCO}_{3} / \gamma \mathrm{Cl}$ coefficient of deep groundwater is 2.24 , indicating that there is a difference in the anionic components between the deep confined water, middle confined water and the diving.

\subsubsection{The Mechanism of Formation of Hydrochemistry}

(1) The formation of shallow brackish water

The study area located on the Yellow River plain undergoes atmospheric precipitation infiltration and lateral recharge from the Yellow River. Due to the high terrain and water level, the hydraulic gradient is about $1 / 2000-1 / 3000$, a larger hydraulic gradient leads to faster runoff, thus leaching and filtration are intense. The hydrochemical type in this area is $\mathrm{HCO}_{3}-\mathrm{Ca}$ type, which is good water quality. The plain away from the Yellow River is characterized by a complex sedimentary environment which has an increase in clay content. Along the direction of the groundwater, flow velocity decreases and the hydraulic gradient is less than $1 / 5000$ (Figure 1). The concentrations of $\mathrm{Na}^{+}, \mathrm{Mg}^{2+}, \mathrm{Cl}^{-}$ and $\mathrm{SO}_{4}{ }^{2-}$ in the groundwater increased and the hydrochemical types changed from $\mathrm{HCO}_{3}-\mathrm{Ca}$ to $\mathrm{HCO}_{3} \cdot \mathrm{Cl}-\mathrm{Na} \cdot \mathrm{Mg}, \mathrm{HCO} \cdot \mathrm{Cl} \cdot \mathrm{SO}_{4}-\mathrm{Na} \cdot \mathrm{Mg}$ and $\mathrm{Cl} \cdot \mathrm{HCO}_{3}-\mathrm{Na} \cdot \mathrm{Mg}$.

Diving in the Jiyang area shows a pattern of horizontal distribution of fresh and brackish water (Figure 3). The old channel rich in water is better and has good water quality. The interfluve between two old channels, having sediments consisting of mainly fine particles, distributed shallow saltwater showing a sporadic shape. This area undergoes atmospheric precipitation recharge and shallow freshwater recharge. The sediments in the interfluve are fine. The groundwater table has a shallow depth, poor runoff conditions and intense evaporation and concentration to form shallow brackish water. Prior to the 1960s, the groundwater head in the middle and deep levels was higher than the ground elevation. In the low-energy region of the regional flow system and the local flow system, brackish water in the mid-level moves upwards due to evaporation, thus forming a modern, shallow saltwater. Although the mixing effect influences the isotope test, it does not affect the analysis result. The shallow brackish water of CFC- 11 and CFC-12 is therefore only $30-50$ years old.

(2) The formation of the middle saltwater

Drilling data shows that the river and lake phase sediments $(40-110 \mathrm{~m})$ in this area mainly comprise clay, silty clay, clip silt, thin silt sand, and clay containing gypsum greater than $5 \mathrm{~cm}$ in diameter. ${ }^{14} \mathrm{C}$ data indicate that the isotopic age of clay at the depth of $43-43.2 \mathrm{~m}$ is $23.79-24.085 \mathrm{ka} \mathrm{BP}$, and that of clay at the depth of $90 \mathrm{~m}$ is 31.56-31.265 ka BP. The age of brackish water depth of $50 \mathrm{~m}$ measured by ${ }^{14} \mathrm{C}$ was $6.43-6.55 \mathrm{ka} \mathrm{BP}$. The ${ }^{14} \mathrm{C}$ datings in the aquifer of figuig indicate that the age of groundwater ranges between 2495 and 10,696 years [14]. The $\delta^{18} \mathrm{O}$ content of this water was $-8.4 \%$. Middle confined saltwater from a depth of 99-110 m was dated to 39-36 ka BP, this water having an $\delta^{18} \mathrm{O}$ content of $-9.0 \sim-9.2 \%$. This time period coincided with the Dali ice age in the Quaternary, resulting in a dry climate [46]. Evaporation and concentration led to an increase in salinity, thus the paleoclimate and sedimentary environment had an important influence on the formation of the middle saltwater.

(3) The dynamic stability of saltwater quality

Due to climatic changes since the Late Pleistocene, alternating glacial and interglacial episodes occurred in the study area. With the exploration depth being $321 \mathrm{~m}$, sedimentary cycles resulting in fine to coarse grained deposits appeared several times (Figure 2). The sand layer was thin and discontinuous, whilst clay and silty clay were abundant. Long-term observation data showed that the water level at different depths had different dynamic characteristics. The dynamics of the shallow groundwater level was mainly controlled by meteorology and hydrology, whose level decreased in the dry season and increased in the wet season. The elevation of the water level was between 20.5-21.5 m, indicating seasonal variation. Middle saltwater had little development and utilization of value. The water level was relatively stable, with a depth of $18-18.5 \mathrm{~m}$. Freshwater at a depth 
of $300-320 \mathrm{~m}$ had a conductivity of $1161-1308 \mathrm{um} / \mathrm{cm}$, a ${ }^{14} \mathrm{C}$ age of $41.74-43.5 \mathrm{ka} \mathrm{BP}$, and $\delta^{18} \mathrm{O}$ content of $-9.8 \sim-9.9 \%$. In the late 1970s, the deep confined water level was about $26 \mathrm{~m}$. Due to poor supply conditions of deep confined water, the water level continued to slowly decline due to over-exploitation (Figure 9), and the rate of decrease was about 0.1-0.5 m/a [47]. At present, the water level is $12.9-13.3 \mathrm{~m}$, this being lower than the middle saltwater level and the diving level. It illustrates that the stable distribution of cohesive soil is a good regional weak aquitard.

Before the 1970s, the groundwater level in the middle and deep layers was higher than shallow groundwater. Over the last 30 years, the groundwater level in the mid-deep layers was lower than shallow groundwater due to the diversion of irrigation water from the Yellow River; however, water quality of the middle saltwater was still stable. Combining groundwater level, dynamic characteristics of water quality, groundwater age and sedimentary environment, groundwater in the study area $(500 \mathrm{~m})$ can be divided into three systems: a shallow partial flow system; an intermediate saltwater flow system; and a deep freshwater flow system (Figure 10). The stable distribution of clay aquitards weakens the vertical hydraulic exchange of saltwater. The combination of the sedimentary environment, clay retardation and hydrogeochemical affect the saltwater quality, and the evolution of saltwater water quality is extremely slow. The alternating flow between the three mobile systems is weak, thus water quality and the water level of the middle brackish water is dynamic and stable, which hass implications for the study and utilization of other similar inland saline waters. These factors have resulted in local populations being unable to exploit this water source for thousands of years, and people have been taking water from $3 \mathrm{~km}$ away for domestic use.

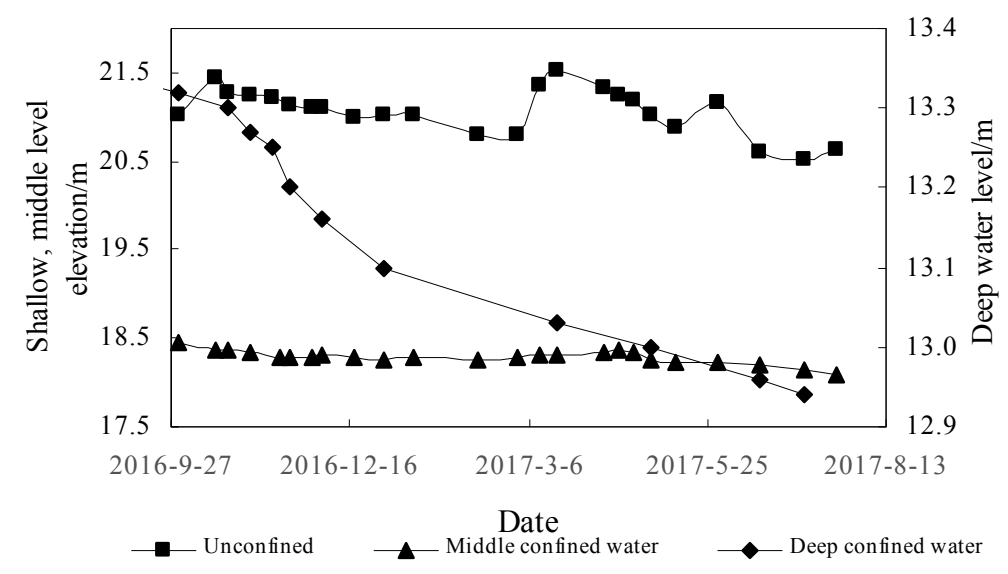

Figure 9. Dynamic characteristics of groundwater level for different types of groundwater.

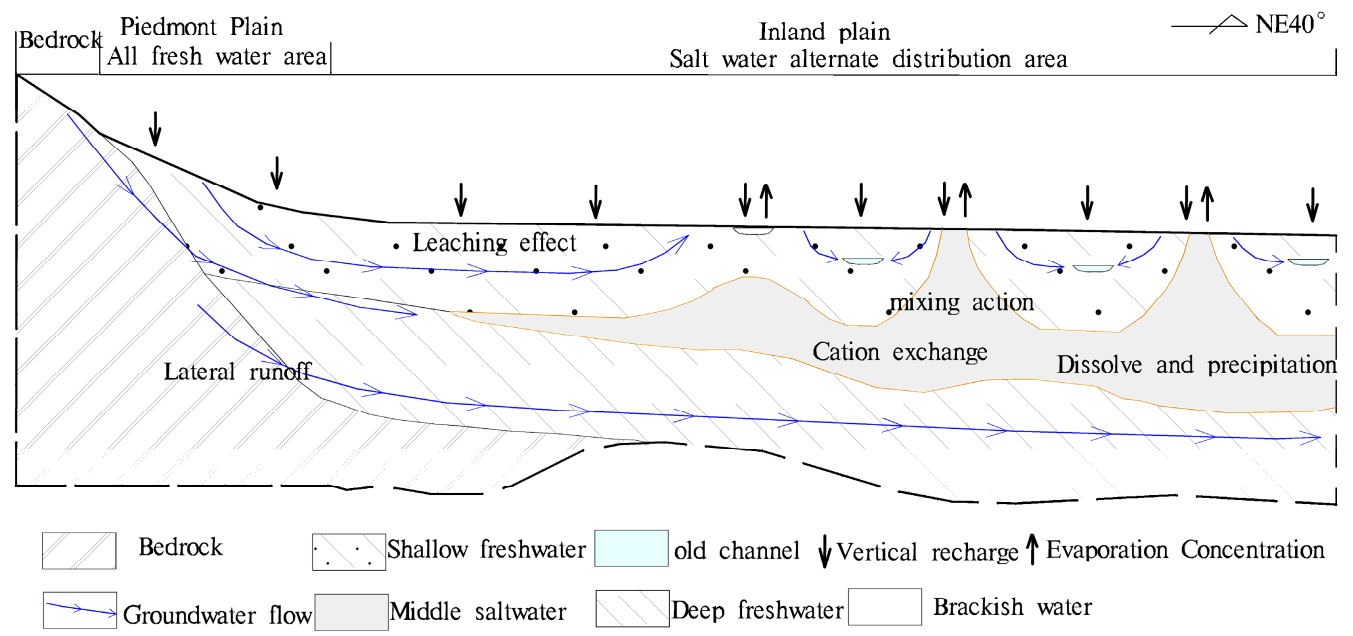

Figure 10. The sketch map of the vertical and horizontal zoning of water chemistry in the study area. 


\section{Conclusions}

(1) The influence of hydrodynamic conditions, sedimentary environment and topography has resulted in a complex groundwater state in the inland plain. TDS increases along the groundwater flow and with the horizontal distribution of freshwater and brackish water (saltwater), showing alternate distribution. Shallow saltwater is distributed in the interfluve between old channels as sporadic or irregular bands.

(2) The optimal isothermal adsorption curves of $\mathrm{Na}^{+}, \mathrm{Ca}^{2+}$ and $\mathrm{Mg}^{2+}$ in groundwater over different depths accord with Henry's equation and Langmuir equation, which is the monolayer chemical adsorption or linear adsorption process. The 6-112 m clay exhibits a large-small-large trend of $\mathrm{Na}^{+}$and $\mathrm{Ca}^{2+}$ retardation in groundwater. The trend of $\mathrm{Mg}^{2+}$ was small-large-small, and the block strength of $\mathrm{Na}^{+}$and $\mathrm{Mg}^{2+}$ in groundwater was higher than that of $\mathrm{Ca}^{2+}$, facilitating a $\mathrm{Na}-\mathrm{Mg}$ or Mg-Na saltwater formation. The correlation between the block strength of clay for $\mathrm{Na}^{+}, \mathrm{Ca}^{2+}$ and $\mathrm{Mg}^{2+}$, and groundwater TDS was strong.

(3) Water quality of middle saltwater was relatively stable. The main hydrochemical types were $\mathrm{Cl} \cdot \mathrm{SO}_{4}-\mathrm{Na} \cdot \mathrm{Mg}$ and $\mathrm{SO}_{4} \cdot \mathrm{Cl}-\mathrm{Mg} \cdot \mathrm{Na}$, which belong to the intermediate circulation system. The dynamic stability of saltwater quality was affected by the stability of clay distribution, its weak permeability and blocking effect, and the sedimentary environment.

(4) Groundwater in the study area is not only affected by complex hydrogeochemistry, such as the leaching effect, cation exchange and evaporation, it is also closely related to the retardation effect of clay. The inland plains area has horizontal and vertical hydrogeochemical zonation characteristics.

Author Contributions: L.X. and X.H. conceived and designed the experiments; L.H. performed the experiments; L.Y. and H.Z. analyzed the data; G.C. and J.X. contributed reagents/materials/analysis tools; L.X. and X.H. wrote the paper.

Funding: This research is supported by the National Natural Science Foundation of China $(41772257,41472216$, 41727225).

Conflicts of Interest: The authors declare no conflict of interest. The founding sponsors had no role in the design of the study; in the collection, analyses, or interpretation of data; in the writing of the manuscript, and in the decision to publish the results.

\section{References}

1. Mehta, S.; Fryar, A.E.; Brady, R.M.; Morin, R.H. Modeling regional salinization of the ogallala aquifer, Southern High Plains, TX, USA. J. Hydrol. 2000, 238, 44-64. [CrossRef]

2. Weisbrod, N.; Dragila, M.I. Potential impact of convective fracture venting on salt-crust buildup and ground-water salinization in arid environments. J. Arid Environ. 2006, 65, 386-399. [CrossRef]

3. Hunter, R.; Day, J.; Shaffer, G.; Lane, R.; Englande, A.; Reimers, R.; Kandalepas, D.; Wood, W.; Day, J.; Hillmann, E. Restoration and management of a degraded baldcypress swamp and freshwater marsh in Coastal Louisiana. Water 2016, 8, 71. [CrossRef]

4. Zhang, Y.; Xu, M.; Li, X.; Qi, J.; Zhang, Q.; Guo, J.; Yu, L.; Zhao, R. Hydrochemical characteristics and multivariate statistical analysis of natural water system: A case study in Kangding County, Southwestern China. Water 2017, 10, 80. [CrossRef]

5. Dedzo, M.G.; Tsozué, D.; Mimba, M.E.; Teddy, F.; Nembungwe, R.M.; Linida, S. Importance of rocks and their weathering products on groundwater quality in Central-East Cameroon. Hydrology 2017, 4, 23. [CrossRef]

6. An, L.S.; Zhao, Q.S.; Ye, S.Y.; Liu, G.Q.; Ding, X.G. Hydrochemical characteristics and formation mechanism of shallow groundwater in the Yellow River Delta. Environ. Sci. 2012, 33, 370-378.

7. Xing, L.; Zhang, F.; Changsuo, L.I.; Yang, L.; Wang, L. Hydro-chemical characteristics of shallow groundwater in the North Shandong Plain. J. Irrig. Drain. 2015, 17, 50-56.

8. Wang, X.S.; Wan, L.; Jiang, X.W.; Li, H.; Zhou, Y.; Wang, J.; Ji, X. Identifying three-dimensional nested groundwater flow systems in a Tóthian Basin. Adv. Water Resour. 2017, 108, 139-156. [CrossRef] 
9. Li, Q.; Zhou, J.; Zhou, Y.; Bai, C.; Tao, H.; Jia, R.; Ji, Y.; Yang, G. Variation of groundwater hydrochemical characteristics in the plain area of the Tarim Basin, Xinjiang Region, China. Environ. Earth Sci. 2014, 72, 4249-4263. [CrossRef]

10. Yuan, J.; Xu, F.; Deng, G.; Tang, Y.; Li, P. Hydrogeochemistry of shallow groundwater in a karst aquifer system of Bijie City, Guizhou Province. Water 2017, 9, 625. [CrossRef]

11. Najib, S.; Fadili, A.; Mehdi, K.; Riss, J.; Makan, A. Contribution of hydrochemical and geoelectrical approaches to investigate salinization process and seawater intrusion in the coastal aquifers of Chaouia, Morocco. J. Contam. Hydrol. 2017, 198, 24-36. [CrossRef] [PubMed]

12. Liao, L.; Jean, J.S.; Chakraborty, S.; Lee, M.K.; Kar, S.; Yang, H.J.; Li, Z. Hydrogeochemistry of groundwater and arsenic adsorption characteristics of subsurface sediments in an Alluvial Plain, SW Taiwan. Sustainability 2016, 8, 1305. [CrossRef]

13. Zhang, W.; Cao, Y.; Jiang, J.; Wang, W.; Duan, L. Numerical simulation of the formation of groundwater chemical components in the Mayukou area, Datong, China. In Proceedings of the International Symposium on Water-Rock Interaction, Kunming, China, 31 July-5 August 2007.

14. Jilali, A.; Fagel, N.; Amar, M.; Abbas, M.; Zarhloule, Y. Hydrogeochemical processes constrained by multivariate statistical methods and isotopic evidence of groundwater recharge in the aquifer of Figuig, Eastern High Atlas of Morocco. Arab. J. Geosci. 2016, 9, 1-11. [CrossRef]

15. Cao, W.; Yang, H.; Liu, C.; Li, Y.; Bai, H. Hydrogeochemical characteristics and evolution of the aquifer systems of Gonghe Basin, Northern China. Geosci. Front. 2018, 9, 907-916. [CrossRef]

16. Awaleh, M.O.; Baudron, P.; Soubaneh, Y.D.; Boschetti, T.; Hoch, F.B.; Egueh, N.M.; Mohamed, J.; Dabar, O.A.; Masse-Dufresne, J.; Gassani, J. Recharge, groundwater flow pattern and contamination processes in an arid volcanic area: Insights from isotopic and geochemical tracers (bara aquifer system, Republic of Djibouti). J. Geochem. Explor. 2017, 175, 82-98. [CrossRef]

17. Swaid, F.A.; Issa, A.A. Deep groundwater quality and its suitability for drinking and agricultural purposes, Wadibaye, Middle Region, Libya. In Sustainable Irrigation and Drainage V: Management, Technologies and Policies; WIT Press: Southampton, UK, 2014; pp. 183-196.

18. Zhihong, L.I.; Fusheng, H.U.; Zhou, W.; Zhao, Z.; Wang, G.; Shi, Z. Hydrogeochemical characteristics and controlling factors of confined water in Yinchuan. Hydrogeol. Eng. Geol. 2017, 44, 31-39.

19. Mustafa, O.; Merkel, B.; Weise, S. Assessment of hydrogeochemistry and environmental isotopes in karst springs of makook anticline, Kurdistan Region, Iraq. Hydrology 2015, 2, 48-68. [CrossRef]

20. Sun, Y.Q.; Qian, H.; Wu, X.-H. Hydrogeochemical modeling of minerals in groundwater in Yinchuan Region. J. Saf. Environ. 2006, 6, 32.

21. Banaś, K. The hydrochemistry of peatland lakes as a result of the morphological characteristics of their basins. Oceanol. Hydrobiol. Stud. 2013, 42, 28-39. [CrossRef]

22. Kolpakova, M.N.; Naymushina, O.S. Zonal features of bog and lake water chemistry along a transect from boreal to arid landscapes in the south of Western Siberia, Russia. IOP Conf. Ser. Earth Environ. Sci. 2016, 44, 022025. [CrossRef]

23. Chen, Q.; Mao, Y.; Cheng, L.I. Hydrochemistry characteristics of shallow groundwater in redbed of Luzhou, Sichuan. China Meas. Test 2013, 39, 42-45.

24. Li, X.; Wu, H.; Qian, H.; Gao, Y. Groundwater chemistry regulated by hydrochemical processes and geological structures: A case study in Tongchuan, China. Water 2018, 10, 338. [CrossRef]

25. Jiang, X.W.; Wan, L.; Wang, X.S.; Li, H.-L. Distribution of groundwater age in drainage basins. Hydrogeol. Eng. Geol. 2012, 4, 003.

26. Feng, X.; Zhang, Y.Z. An analysis of the ions ratio coefficients of groundwater in Shenzhou area. China Rural Water Hydropower 2014, 4, 18-21.

27. Zhang, G.X.; Wei, D.; Yan, H.E.; Salama, R. Hydrochemical characteristics and evolution laws of groundwater in Songnen Plain, Northeast China. Adv. Water Sci. 2006, 17, 20-28.

28. Xing, W.; Ma, R.; Sun, Z.; Hu, Y.; Ge, M.; Chang, Q. Hydrochemical characteristics and water quality assessment of groundwater in the Dunhuang Basin, Northwestern China. Geol. Sci. Technol. Inf. 2016, 35, 196-202.

29. Loni, O.A.; Zaidi, F.K.; Alhumimidi, M.S.; Alharbi, O.A.; Hussein, M.T.; Dafalla, M.; Alyousef, K.A.; Kassem, O.M.K. Evaluation of groundwater quality in an evaporation dominant arid environment; A case study from al asyah area in Saudi Arabia. Arab. J. Geosci. 2015, 8, 6237-6247. [CrossRef] 
30. Nakagawa, K.; Amano, H.; Kawamura, A.; Berndtsson, R. Classification of groundwater chemistry in Shimabara, using self-organizing maps. Hydrol. Res. 2017, 48, 840-850. [CrossRef]

31. Sherwood, J.D.; Craster, B. Transport of water and ions through a clay membrane. J. Colloid Interface Sci. 2000, 230, 349-358. [CrossRef] [PubMed]

32. Yamei, L.I.; Cheng, J.; Minmin, L.I.; Cui, L. Experimental study on migration and transformation in cohesive soil of salt water. Water Resour. Prot. 2015, 31, 88-93.

33. Ishiguro, M.; Matsuura, T.; Detellier, C. Reverse osmosis separation for a montmorillonite membrane. J. Membr. Sci. 1995, 107, 87-92. [CrossRef]

34. Saber, M.; Abdelshafy, M.; Faragallah, E.A.A.; Abd-Alla, M.H. Hydrochemical and bacteriological analyses of groundwater and its suitability for drinking and agricultural uses at Manfalut District, Assuit, Egypt. Arab. J. Geosci. 2014, 7, 4593-4613. [CrossRef]

35. Yin, J.; Deng, C.; Yu, Z.; Wang, X.; Xu, G. Effective removal of lead ions from aqueous solution using nano illite/smectite clay: Isotherm, kinetic, and thermodynamic modeling of adsorption. Water 2018, 10, 210. [CrossRef]

36. Zhang, Y.; Fu, C.; Mao, L.; Gong, X.L.; Li, X.-Q. Hydrochemical characteristics and formation mechanism of the groundwater in Yancheng, Jiangsu Province. Resour. Environ. Yangtze Basin 2017, 26, 598-605.

37. Xu, W.; Zhang, J.; Liu, Y. Degradation of organic matter and ammonia nitrogen in constructed rapid infiltration system. Fresenius Environ. Bull. 2011, 20, 1685-1690.

38. Maleki, S.; Karimi-Jashni, A. Effect of ball milling process on the structure of local clay and its adsorption performance for Ni(II) removal. Appl. Clay Sci. 2017, 137, 213-224. [CrossRef]

39. Yechieli, Y.; Wood, W.W. Hydrogeologic processes in saline systems: Playas, sabkhas, and saline lakes. Earth Sci. Rev. 2002, 58, 343-365. [CrossRef]

40. Yang, Y.; Xing, L.T.; Zhang, W.J.; Xiang, H.; Song, G.Z.; Chi, G.Y.; Hou, X.Y. The retardation of clay in shallow groundwater system of inland plains. Sci. Technol. Eng. 2017, 17, 50-56.

41. Huang, L.; Wang, L.; Zhang, Y.; Xing, L.; Hao, Q.; Xiao, Y.; Yang, L.; Zhu, H. Identification of groundwater pollution sources by a SCE-UA algorithm-based simulation/optimization model. Water 2018, 10, 193. [CrossRef]

42. Hui, B.; Ping, H. Experimental study of water and salt redistribution of clay soil in an opening system with constant temperature. Environ. Geol. 2008, 55, 717-721.

43. Zhang, Z.; Qin, Y.; Wang, G.X.; Fu, X.H. Numerical description of coalbed methane desorption stages based on isothermal adsorption experiment. Sci. China Earth Sci. 2013, 56, 1029-1036. [CrossRef]

44. Vimonses, V.; Lei, S.; Bo, J.; Chow, C.W.K.; Saint, C. Kinetic study and equilibrium isotherm analysis of Congo red adsorption by clay materials. Chem. Eng. J. 2009, 148, 354-364. [CrossRef]

45. Nelson, C.; Mildenhall, D.; Todd, A.; Pocknall, D. Subsurface stratigraphy, paleoenvironments, palynology, and depositional history of the late neogene tauranga group at ohinewai, lower waikato lowland, South Auckland, New Zealand. N. Z. J. Geol. Geophys. 1988, 31, 21-40. [CrossRef]

46. Sugita, F.; Gillham, R.W. Pore scale variation in retardation factor as a cause of nonideal reactive breakthrough curves: 3. Column investigations. Water Resour. Res. 1995, 31, 121-128. [CrossRef]

47. Zhang, Z.; Shi, D.; Ren, F.; Yin, Z.; Sun, J.; Zhang, C. Evolution of quaternary groundwater system in North China plain. Sci. China 1997, 40, 276-283. [CrossRef]

(C) 2018 by the authors. Licensee MDPI, Basel, Switzerland. This article is an open access article distributed under the terms and conditions of the Creative Commons Attribution (CC BY) license (http:/ / creativecommons.org/licenses/by/4.0/). 